\title{
PCR amplification of GC-rich DNA regions using the nucleotide analog $\mathrm{N}^{4}$-methyl-2'-deoxycytidine 5 'triphosphate
}

\author{
Cyntia R. Flores-Juárez¹, Eva González-Jassoํ․, Anaid Antaramian², and Reynaldo C. Pless ${ }^{1}$ \\ ${ }^{1}$ CICATA, Instituto Politécnico Nacional, Querétaro, Querétaro, 76090, Mexico and ${ }^{2}$ Instituto de \\ Neurobiología, Universidad Nacional Autónoma de México, Juriquilla, Querétaro, 76230, Mexico
}

BioTechniques 61:175-182 (October 2016) doi 10.2144/000114457

Keywords: GC-rich DNA; PCR; N4-methylcytosine; dCTP analog

Supplementary material for this article is available at www.BioTechniques.com/article/114457.

GC-rich DNA regions were PCR-amplified with Taq DNA polymerase using either the canonical set of deoxynucleoside triphosphates or mixtures in which the dCTP had been partially or completely replaced by its $\mathrm{N}^{4}$-methylated analog, $\mathrm{N}^{4}$-methyl-2'-deoxycytidine $5^{\prime}$-triphosphate ( $\mathrm{N}^{4} \mathrm{me}$ - $\mathrm{dCTP}$ ). In the case of a particularly GC-rich region (78.9\% GC), the PCR mixtures containing $\mathrm{N}^{4} \mathrm{me}$ - $\mathrm{dCTP}$ produced the expected amplicon in high yield, while mixtures containing the canonical set of nucleotides produced numerous alternative amplicons. For another GC-rich DNA region (80.6\% GC), the target amplicon was only generated by re-amplifying a gel-purified sample of the original amplicon with $\mathrm{N}^{4}$ me-dCTP-containing PCR mixtures. In a direct PCR comparison on a highly GC-rich template, mixtures containing $\mathrm{N}^{4}$ me-dCTP clearly performed better than did solutions containing the canonical set of nucleotides mixed with various organic additives (DMSO, betaine, or ethylene glycol) that have been reported to resolve or alleviate problems caused by secondary structures in the DNA. This nucleotide analog was also tested in PCR amplification of DNA regions with intermediate GC content, producing the expected amplicon in each case with a melting temperature $\left(T_{m}\right)$ clearly below the $T_{m}$ of the same amplicon synthesized exclusively with the canonical bases.

GC-rich regions are found in $>60 \%$ of gene promoters in higher eukaryotes (1). Most housekeeping and tumor suppressor genes, as well as $\sim 40 \%$ of tissue-specific genes, contain high-GC sequences in their promoter regions (2). Therefore, the study of GC-rich regions is of great interest in biological and clinical investigations. The amplification of genes of interest by PCR is an essential step in the study of their function and regulation, but DNA regions that are $>60 \%$ GC require special PCR protocols due to their complex and strong secondary structures that resist denaturation and interfere with primer annealing. Secondary structures can also block the advance of DNA polymerase during the extension step, resulting in poor amplification of the desired products or in the amplification of shortened PCR products lacking the sequence containing the secondary structure (3-8).

There are a large number of protocols for amplification of GC-rich DNA. Some methodologies involve protocols such as stepdown PCR, slowdown PCR, or PCR with multiple heat pulses during the extension phase $(8,9)$. Certain organic co-solvents such as DMSO, formamide, and ethylene glycol have been shown to facilitate DNA strand separation by disrupting base pairing, and other agents such as tetraalkylammonium (TAA) salts and betaine have also been used (10-13); however, high concentrations of these additives inhibit DNA polymerase activity $(14,15)$. In a different approach, nucleotide analogs such as 7-deaza-2'-deoxyguanosine (c $c^{7}$ dGTP), 2'-deoxyinosine 5'-triphosphate (dITP), and $\mathrm{N}^{4}$-methyl-2'-deoxycytidine $5^{\prime}$-triphosphate $\left(\mathrm{N}^{4} \mathrm{me}\right.$-dCTP) have been reported as being useful by destabilizing $\mathrm{G}: \mathrm{C}$ base pairs $(9,16)$.

Compared with cytosine, the analog $\mathrm{N}^{4}$-methylcytosine $\left(\mathrm{N}^{4} \mathrm{meC}\right)$ forms a

\section{METHOD SUMMARY}

Here, we report use of the nucleotide analog N44-methyl-2'-deoxycytidine 5 '-triphosphate to partially or totally replace dCTP in PCR amplification of high-GC content DNA regions resistant to amplification using the canonical set of nucleotides. 
less stable base pair with guanine, with a stability similar to that of the A:T base pair (17). The methyl group in $\mathrm{N}^{4} \mathrm{meC}$ can be positioned either cis or trans to $\mathrm{N}^{3}$; when the methyl group is in the cis position it will not allow the formation of the Watson-Crick base pair, resulting in a destabilization of the duplex, whereas in the trans position the $\mathrm{N}^{4}$-methyl group protrudes into the mayor groove, interfering with the local hydration structure, again destabilizing $\mathrm{N}^{4}$-methylated analog of $\mathrm{dCTP}$, in the amplification of DNA regions with moderate GC-content has previously been reported (19). Subsequently, PCR amplicons containing $\mathrm{N}^{4} \mathrm{meC}$ were compared with those containing unmodified cytosine for hybridization on microarrays, with the $\mathrm{N}^{4} \mathrm{meC}$ amplicons generally performing better (20).

Here, we examined PCR amplification of GC-rich DNA regions, either using the normal complement of nucleotides in the PCR mixture or replacing dCTP with $\mathrm{N}^{4}$ me-dCTP, to determine if there is any advantage gained by using this analog. In addition, the effects of some of the above-mentioned additives on PCR were also compared. It was found that the use of $\mathrm{N}^{4} \mathrm{me}$-dCTP affords substantial benefits in the amplification of DNA sequences with high GC content and that these benefits exceed those attainable with commonly used co-solvents and additives.

\section{Materials and methods}

Primer design

Primer pairs were designed to amplify GC-rich segments located in various the DNA duplex (18).

The use of $N^{4} m e-d C T P$, the

human genes (Table 1) using the PrimerQuest program from Integrated DNA Technologies (IDT, Coralville, IA). Primers were selected that contained the fewest possible guanines in their sequence in order to minimize the reduction of the primer hybridization temperature for the DNA template containing $\mathrm{N}^{4} \mathrm{meC}$ (19). Primers were also evaluated for their tendency to form homodimers, heterodimers, and hairpin structures using the OligoAnalyzer program (IDT). Finally, primers were evaluated with primer-BLAST (www.ncbi.nlm.nih.gov/ tools/primer-blast/) to ensure their uniqueness within the human genome.

\section{PCR experiments}

All PCR experiments were performed in a LightCycler 1.5 thermocycler (Roche, Basel, Switzerland) in borosilicate glass capillaries (Roche). PCR was carried out in a total volume of $10 \mu \mathrm{L}$. The amplification mixtures contained 30 ng of human genomic DNA (Roche); $0.5 \mu \mathrm{M}$ of each primer (IDT); PCR buffer $(50 \mathrm{mM} \mathrm{KCl}, 10 \mathrm{mM}$ Tris-HCl, $\mathrm{pH}$ 8.3) (Sigma-Aldrich, St. Louis, $\mathrm{MO}) ; 200 \mu \mathrm{M}$ of each deoxyribonucleotide (dATP, dGTP, dTTP, and dCTP) (Sigma-Aldrich) or $200 \mu \mathrm{M} \mathrm{N}{ }^{4}$ me-dCTP (TriLink Biotechnologies, San Diego, CA) instead of dCTP in the case of modified amplicons; $1.5 \mathrm{U}$ HotStart Taq DNA polymerase (Sigma-Aldrich); 2.5 $\mathrm{mM} \mathrm{MgCl}$ (Sigma-Aldrich); and SYBR Green I (Invitrogen, Carlsbad, CA) at a final concentration of $0.4 \times$

To evaluate the usefulness of $\mathrm{N}^{4}$ me-dCTP in the amplification of highly GC-rich target sequences, we selected regions in the human $A R X$ and GNAS1 genes (78.9\% GC and $80.6 \%$ $\mathrm{GC}$, respectively).

Table 1. Main characteristics of the primers designed for this study.

\begin{tabular}{|c|c|c|c|c|c|}
\hline Gene & GenBank & $\begin{array}{c}\text { Primer sequence } \\
5^{\prime}-3^{\prime}\end{array}$ & $\begin{array}{c}\mathrm{T}_{\mathrm{m}} \\
\left({ }^{\circ} \mathrm{C}\right)\end{array}$ & $\begin{array}{l}\text { Product length } \\
\text { (bp) }\end{array}$ & $\begin{array}{l}\text { GC } \\
(\%)\end{array}$ \\
\hline GNAS 1 & $\mathrm{AH} 002748$ & $\begin{array}{l}\text { TCCTCСTCСTCСTTCCACC } \\
\text { CGCCGCTCTTATTGCCT }\end{array}$ & $\begin{array}{l}61.6 \\
61.8\end{array}$ & 124 & 80.6 \\
\hline$A R X$ & NG_008281 & $\begin{array}{l}\text { CCCGCAGGCTCCCCTAA } \\
\text { CTCATCTTCTTCGTCCTCCAG }\end{array}$ & $\begin{array}{l}65.5 \\
61.2\end{array}$ & 522 & 78.9 \\
\hline$B R A F$ & NG_007873.2 & $\begin{array}{l}\text { CTCGGTTATAAGATGGCGGCGCTGA } \\
\text { AGTCGGGAGGGCGGCAGGGT }\end{array}$ & $\begin{array}{l}72.1 \\
71.6\end{array}$ & 185 & 74.6 \\
\hline NSMCE2 & NT_008046 & $\begin{array}{l}\text { CCGCCTCCTGGTGACTCACGCT } \\
\text { GCCGCCTCCTGCCCAGCCCC }\end{array}$ & $\begin{array}{l}70.3 \\
76.4\end{array}$ & 308 & 70.8 \\
\hline TFPI-2 & AY044097 & $\begin{array}{l}\text { CGTCCCCGTCTGGACTACAGGAGAAAG } \\
\text { CCCGCTGGGCAAGGCGTCCGAGAAAGC }\end{array}$ & $\begin{array}{l}63.3 \\
70.5\end{array}$ & 267 & 67.2 \\
\hline ACTB & NG_007992.1 & $\begin{array}{l}\text { GCTAAGTCCTGCCCTCATTT } \\
\text { GACACCCACCTTGATCTTCAT }\end{array}$ & $\begin{array}{l}62.0 \\
62.0 \\
\end{array}$ & 220 & 55.5 \\
\hline GAPDH & NG_007073.2 & $\begin{array}{l}\text { СТСТСТСССАТСССТTСТСС } \\
\text { СССАССССТTСТСТААGTСС }\end{array}$ & $\begin{array}{l}60.3 \\
59.9\end{array}$ & 195 & 54.4 \\
\hline
\end{tabular}

For the comparison between additives, we chose to amplify the $A R X$ gene. Additives were used in the following concentrations: $2.5 \%-10 \%$ DMSO (Sigma-Aldrich), 0.5-2 M betaine (Sigma-Aldrich), and 0.5-1.5 $\mathrm{M}$ ethylene glycol (Fermont, Mexico City, Mexico).

Other less GC-rich segments were also amplified with $\mathrm{N}^{4}$ me-dCTP in order to determine the $T_{m}$ reduction of the amplicons when $\mathrm{N}^{4} \mathrm{meC}$ was incorporated.

\section{Cycling protocols}

The standard thermal program used was: $95^{\circ} \mathrm{C}$ for $1 \mathrm{~min}$; followed by 45 cycles of $95^{\circ} \mathrm{C}$ for $30 \mathrm{~s} ; 62^{\circ} \mathrm{C}, 64^{\circ} \mathrm{C}$, or $66^{\circ} \mathrm{C}$ for $30 \mathrm{~s}$; and $72^{\circ} \mathrm{C}$ for $60 \mathrm{~s}$; with a final extension at $72^{\circ} \mathrm{C}$ for $4 \mathrm{~min}$. The slowdown program (9) used a heating rate of $2.5^{\circ} \mathrm{C} \mathrm{s}^{-1}$ and a cooling rate of $1.5^{\circ} \mathrm{C} \mathrm{s}^{-1}$, with temperatures of $95^{\circ} \mathrm{C}$ for $1 \mathrm{~min}$, then 37 cycles of $94^{\circ} \mathrm{C}$ for $30 \mathrm{~s}$, annealing for $30 \mathrm{~s}$ at the temperatures detailed below, and $72^{\circ} \mathrm{C}$ for $1 \mathrm{~min}$, followed by a final extension at $72^{\circ} \mathrm{C}$ for $4 \mathrm{~min}$. The annealing temperature was set at $70^{\circ} \mathrm{C}$ for the first 2 cycles and then reduced by $1^{\circ} \mathrm{C}$ every second cycle until $60^{\circ} \mathrm{C}$ was reached (22 total cycles for 11 steps of decreasing annealing temperature); this was followed by 15 additional cycles with annealing at $60^{\circ} \mathrm{C}$.

\section{PCR product characterization}

PCR products were evaluated by amplicon melting temperature $\left(T_{m}\right)$, which was obtained from the melting curves (Supplementary Material) provided by the LightCycler 1.5 computer automatically after thermocycling. Furthermore, all PCR products were analyzed by agarose gel electrophoresis: $7-\mu \mathrm{L}$ aliquots of the PCR mixtures were applied in loading buffer (0.25\% xylene cyanol, $0.25 \%$ bromophenol blue, $30 \%$ glycerol) to $2 \%$ agarose gels (Invitrogen) in 1× TBE buffer (Invitrogen) and electrophoresed in a subcell GT electrophoresis chamber (Bio-Rad, Hercules, CA) at 85 $\checkmark$ for $60 \mathrm{~min}$. The gels were stained in aqueous ethidium bromide $(0.2 \mu \mathrm{g} / \mathrm{mL})$, rinsed with water, and photographed on a transilluminator $(320 \mathrm{~nm}$ ) (Model LMS-20E; Ultra-Violet Products Ltd., Cambridge, UK). For size standards, a 100-bp or 50-bp DNA marker ladder 
A

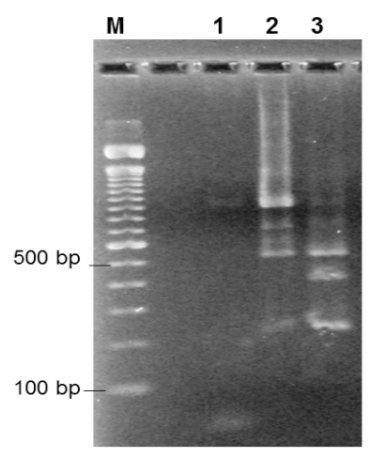

B

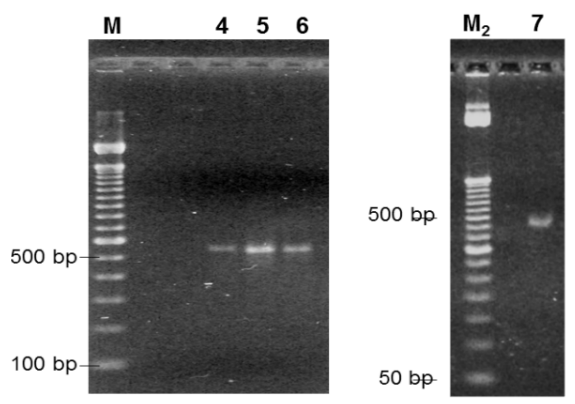

Figure 1. PCR amplification of the $A R X$ gene (522 bp). PCR products were analyzed by agarose gel electrophoresis. (A) Amplification with the normal nucleotides and different hybridization temperatures. Lane M: 100-bp ladder; Lane 1: hybridization at $62^{\circ} \mathrm{C}$; Lane 2: hybridization at $64^{\circ} \mathrm{C}$; Lane 3: slowdown protocol. (B) Amplification with the slowdown protocol and different ratios of $\mathrm{N}^{4} \mathrm{me}-\mathrm{dCTP}: \mathrm{dCTP}$ or complete replacement of dCTP with $\mathrm{N}^{4} \mathrm{me}$ dCTP. Lane M: 100-bp ladder; Lane $\mathrm{M}_{2}$ : 50bp ladder; Lane 4: $\mathrm{N}^{4} \mathrm{me}-\mathrm{dCTP}$ :dCTP (10:1): Lane 5: N4me-dCTP:dCTP (5:1); Lane 6: $\mathrm{N}^{4} \mathrm{me}$-dCTP:dCTP (3:1); Lane 7: $\mathrm{N}^{4} \mathrm{me}$-dCTP.

from Invitrogen was used. Sequencing was performed at LANGEBIO, Irapuato, Mexico by the Sanger method using capillary sequencing technology.

\section{Results and discussion}

Previously, we demonstrated the capacity of $N^{4} m e-d C T P$ in the reaction mixture to produce specific PCR products with reduced $T_{m}$ values from DNA regions with moderate $G C$ content (19). Here, GC-rich segments of different human genes were tested by PCR amplification using a reaction mixture containing the canonical set of nucleoside triphosphates at 200 $\mu \mathrm{M}$ each or one in which dCTP was replaced with $\mathrm{N}^{4} \mathrm{me}$-dCTP, either completely $(200 \mu \mathrm{M})$ or with various proportions of $\mathrm{N}^{4} \mathrm{me}-\mathrm{dCTP}$ :dCTP [i.e., 10:1 (182 $\mu \mathrm{M}: 18 \mu \mathrm{M}), 5: 1$ (167 $\mu \mathrm{M}: 33$ $\mu \mathrm{M})$, or 3:1 (150 $\mu \mathrm{M}: 50 \mu \mathrm{M})]$. Figure 1 shows the amplification reactions for the $A R X$ gene using either a canonical nucleotide mix or mixes containing $\mathrm{N}^{4} \mathrm{me}$-dCTP in different proportions. PCR amplifications conducted with the canonical complement of nucleotides and different thermal profiles produced spurious electrophoretic bands in all cases (Figure 1A). In contrast, amplifications performed with $\mathrm{N}^{4} \mathrm{me}$-dCTP in different proportions produced a single specific band of the expected molecular size (Figure 1B). Similarly, when the dCTP was completely replaced by $\mathrm{N}^{4} \mathrm{me}$-dCTP, the specific band was again obtained (Figure 1B, Lane 7).

Analysis of possible hairpin structures in the ARX gene by the OligoAnalyzer program shows the potential for two extensive hairpin structures formed mainly by $\mathrm{G}: \mathrm{C}$ base pairs in the central region of the desired amplicon (Supplementary Material), with $\Delta G$ values of -6.49 and $-0.84 \mathrm{kcal} / \mathrm{mol}$ at $72^{\circ} \mathrm{C}$ and $50 \mathrm{mM} \mathrm{NaCl}$. These hairpins might block the advance of DNA polymerase during the extension step, resulting in a shorter amplicon due to the enzyme skipping past the hairpin or other amplicons, including longer ones, due to the opportunistic amplification of less difficult to amplify regions of the genome. In contrast, when $\mathrm{N}^{4} \mathrm{meC}$ is incorporated by the DNA polymerase during PCR, the resulting DNA product acts as a better template for subsequent PCR amplifications, likely as a result of weaker $\mathrm{G}: \mathrm{N}^{4} \mathrm{meC}$ base pairs leading to less stable hairpin structures. Upon replacing the G:C pairs in the hairpin-prone regions by $\mathrm{A}: \mathrm{T}$ pairs (for a rough approximation of the energetics of $\mathrm{G}: \mathrm{N}^{4} \mathrm{meC}$ pairs, see Reference 17) the OligoAnalyzer program predicts only a very weak hairpin in the sequence of interest, with $\Delta \mathrm{G}=+0.98 \mathrm{kcal} / \mathrm{mol}$ at $72^{\circ} \mathrm{C}$ and $50 \mathrm{mM} \mathrm{NaCl}$.

The 522-bp PCR product of the $A R X$ gene, obtained using $\mathrm{N}^{4} \mathrm{me}-\mathrm{dCTP}$ instead of dCTP or with 10:1 $\mathrm{N}^{4} \mathrm{me}-\mathrm{dCTP}: \mathrm{dCTP}$, was isolated from the gel and sequenced using the reverse primer. This gave the correct sequence over the length of the amplicon, and it aligned with the sequence in the NCBI Nucleotide database when searched with BLAST, confirming that the desired
A

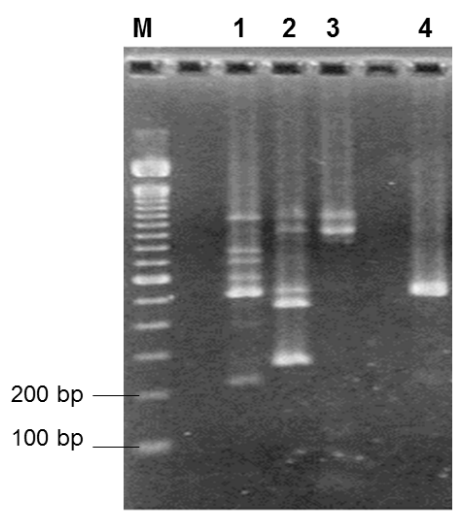

B

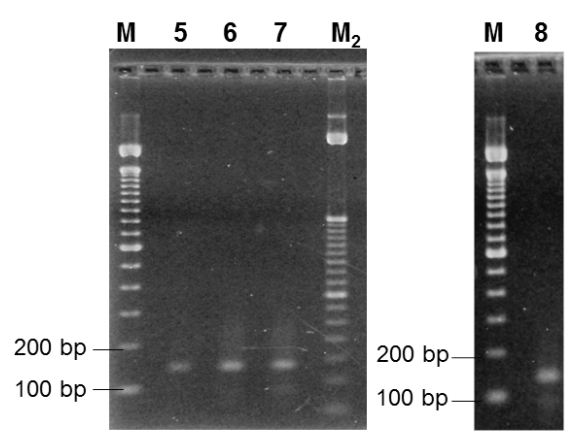

Figure 2. PCR amplification of the GNAS1 gene (124 bp). PCR products were analyzed by agarose gel electrophoresis. (A) Amplification with the normal nucleotides and different hybridization temperatures. Lane M: 100-bp DNA ladder; Lane 1: hybridization at $66^{\circ} \mathrm{C}$; Lane 2: hybridization at $64^{\circ} \mathrm{C}$; Lane 3: hybridization at $62^{\circ} \mathrm{C}$; Lane 4: slowdown protocol. (B) Reamplification of the purified faint band obtained from an initial PCR (with dATP/dGTP/dTTP/dCTP and $10 \%$ DMSO) using the slowdown program and different ratios of $\mathrm{N}^{4} \mathrm{me}-\mathrm{dCTP}$ :dCTP or replacing dCTP with $\mathrm{N}^{4}$ medCTP. Lane 5: $\mathrm{N}^{4} \mathrm{me}-$ dCTP:dCTP (10:1); Lane 6: Nme-dCTP:dCTP (5:1); Lane 7: N ${ }^{4}$ me-dCTP:dCTP (3:1); Lane $\mathrm{M}_{2}$ : 50-bp DNA ladder; Lane 8: $\mathrm{N}^{4} \mathrm{me}-\mathrm{dCTP}$.

amplicon had indeed been obtained. It should also be noted that the potential hairpin structures did not interfere with sequencing, probably because these structures were relatively destabilized in the template DNA due to the partial or total replacement of the cytosines with $\mathrm{N}^{4} \mathrm{meCs}$.

We also compared amplification of the GNAS1 gene using the different nucleotide mixes. Using the canonical set of nucleotides and testing different PCR programs, the desired 124-bp amplicon was not obtained; instead, the product mixtures contained a number of unwanted larger amplicons, whose identity and distribution varied with the different PCR 
thermal programs used (Figure 2A). It was also not possible to produce the desired 124-bp amplicon even when the $N^{4}$ me-dCTP nucleotide was used, either with different $\mathrm{N}^{4}$ me-dCTP:dCTP input ratios or complete replacement of the canonical nucleotide with the $\mathrm{N}^{4}$-methylated analog. However, the desired product was obtained by first conducting a PCR with the canonical set of nucleotides in 10\% DMSO, isolating the desired faint band from the agarose gel using the QIAquick gel extraction kit from QIAGEN (Hilden, Germany), and reamplifying this purified material by PCR with the same pair of primers without DMSO and either with mixtures of $N^{4}$ me-dCTP:dCTP or with $\mathrm{N}^{4}$ me-dCTP only. This provided satisfactory yields in all cases (Figure 2B). Here, secondary-structure analysis by the OligoAnalyzer program showed one of the two primer hybridization sites to be involved formation of a strong hairpin structure with a neighboring stretch of DNA, which should preclude efficient priming.

Regions with lower GC-content (54.4\%-74.6\%) from different human
Table 2. Melting temperature $\left(T_{m}\right)$ values for different gene fragments amplified with the normal set of nucleotides or with replacement of dCTP by $\mathrm{N}^{4}$ me-dCTP.

\begin{tabular}{|c|c|c|c|}
\hline Gene & \multicolumn{1}{c}{$\begin{array}{c}\text { Normal } \\
\text { amplicon } \\
\mathbf{T}_{\mathbf{m}}\left({ }^{\circ} \mathbf{C}\right)\end{array}$} & $\begin{array}{c}\text { Modified } \\
\text { amplicon } \\
\mathbf{T}_{\mathbf{m}}\left({ }^{\circ} \mathbf{C}\right)\end{array}$ & \multicolumn{1}{c|}{$\begin{array}{c}\Delta \mathbf{T}_{\mathbf{m}} \\
\left({ }^{\circ} \mathbf{C}\right)\end{array}$} \\
\hline GNAS1 & 88.1 & 78.6 & -9.5 \\
\hline ARX & 87.0 & 76.4 & -10.6 \\
\hline BRAF & 95.1 & 86.0 & -9.1 \\
\hline NSMCE2 & 95.7 & 84.4 & -11.3 \\
\hline TFPI-2 & 94.7 & 85.0 & -9.7 \\
\hline ACTB & 89.6 & 79.1 & -10.5 \\
\hline GAPDH & 87.4 & 78.7 & -8.7 \\
\hline
\end{tabular}

genes (BRAF, NSMCE2, TFPI-2, $A C T B, G A P D H)$ were amplified using $\mathrm{N}^{4} \mathrm{me}-\mathrm{dCTP}$ instead of dCTP. All PCR amplifications yielded the target amplicons. Table 2 shows the $T_{m}$ values for all fragments amplified in both versions of the PCR mixture, namely, with the canonical set of nucleotides or with complete replacement of dCTP with $N^{4}$ me-dCTP. For the amplified fragments, the $\Delta T_{m}$ values obtained for the normal and the modified version of the same amplicon ranged from $-8.7^{\circ} \mathrm{C}$ to $-11.3^{\circ} \mathrm{C}$; contrary to what might have been expected, these $T_{m}$ differences did not correlate with the GC content of the amplicons. Thus, GNAS1, the most GC-rich amplicon (80.6\% GC), showed a reduction in $\mathrm{T}_{\mathrm{m}}$ of $9.5^{\circ} \mathrm{C}$ when cytosine was replaced with $\mathrm{N}^{4} \mathrm{meC}$, while the much less GC-rich fragment ACTB (55.5\% GC), showed a $T_{m}$ reduction of $10.5^{\circ} \mathrm{C}$, suggesting that there are other factors besides the fractional GC-content involved in determining the specific melting-temperature differences of the amplicons.

Previous efforts to amplify GC-rich regions have focused on the use of organic compounds such as dimethyl sulfoxide (DMSO), betaine, ethylene glycol, or formamide, among others. These approaches have generally required optimization of the additive concentration and sometimes even the combination of two or more additives to achieve satisfactory amplification. To evaluate $\mathrm{N}^{4}$ me-dCTP in comparison with $\mathrm{PCR}$ additives, the 522-bp region from the $A R X$ gene was amplified using $\mathrm{N}^{4} \mathrm{me}$-dCTP or using the canonical complement of nucleotides with added DMSO, betaine, or ethylene glycol. Gel electrophoresis (Figure 3, Lane 2)

- a smarter approach to automated 96/384-well pipetting.

Three interchangeable heads - pipette from $0.5 \mu \mathrm{L}$ to $1000 \mu \mathrm{L}$

- Programmable features, such as mixing and multi-dispense

- Automated tip loading for perfect seals on all 96 channels

- Large touchscreen - so easy and intuitive, everyone in the lab will want to use it

\section{Enter to win!}

- www.mt.com/Rainin-BenchSmart

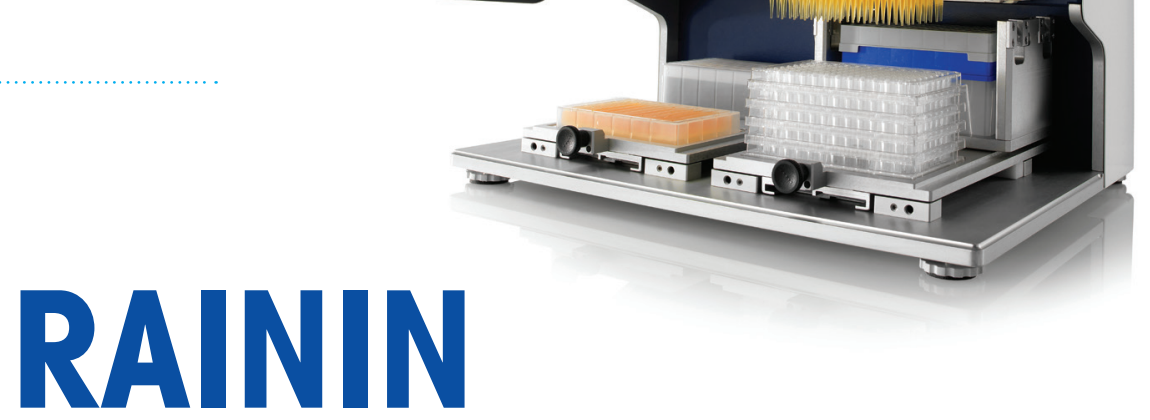



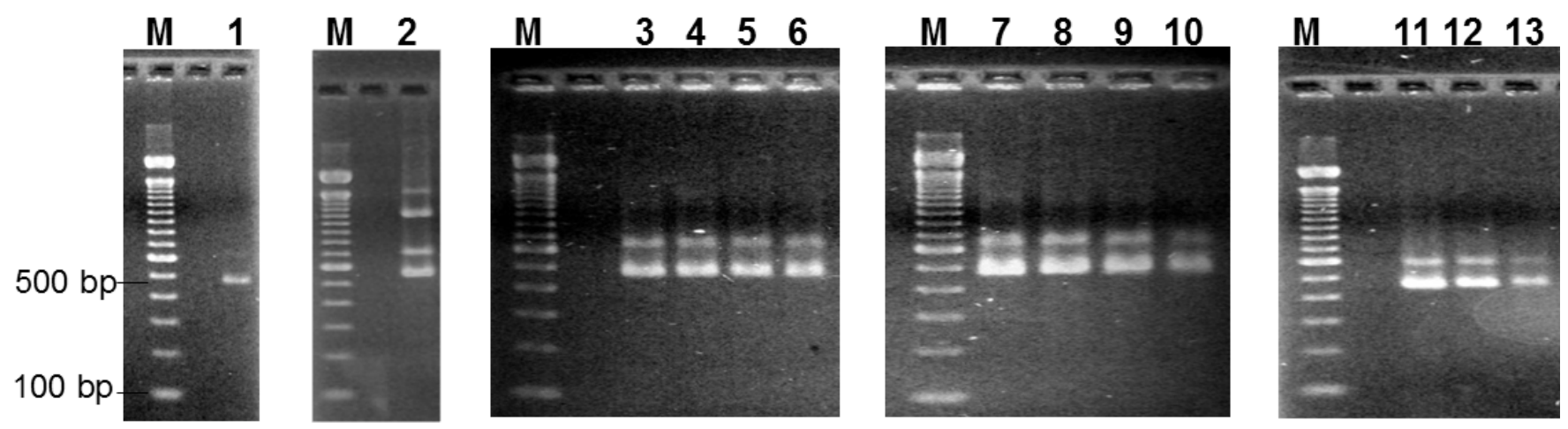

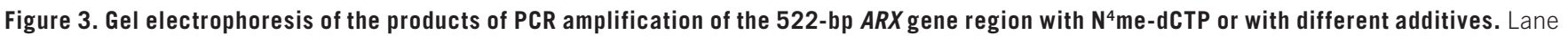
1: PCR amplification with $\mathrm{N}^{4}$ me-dCTP replacing dCTP, without additives; Lane 2: amplification with dATP/dGTP/dTTP/dCTP. Lanes 3-6: amplification with $\mathrm{dATP} / \mathrm{dGTP} / \mathrm{dTTP} / \mathrm{dCTP}$, with $2.5 \%, 5 \%, 7.5 \%$, or 10\% DMSO. Lanes 7-10: amplification with dATP/dGTP/dTTP/dCTP, with 0.5 M, $1.5 \mathrm{M}$, or $2 \mathrm{M}$ betaine; Lanes 11-13: amplification with dATP/dGTP/dTTP/dCTP, with 0.5 M, $1 \mathrm{M}$, or $1.5 \mathrm{M}$ ethylene glycol; Lanes M: 100-bp DNA marker.

illustrates the difficulty of PCR amplification for this highly GC-rich region (78.9\% GC) when neither the nucleotide analog nor any additive is used; at least 3 nonspecific products are evident. The use of $\mathrm{N}^{4} \mathrm{me}$-dCTP results in amplification of the correct target, and reduces non-specific amplification (Figure 3, Lane 1). Using the canonical set of nucleotides with $2.5 \%-10 \%$ DMSO, as commonly reported $(5,21,22)$, there is a reduction in the number of nonspecific products, but in no case is the $522-b p$ fragment obtained as the sole amplification product (Figure 3, Lanes 3-6). DMSO concentrations $>10 \%$ were not tested, as they are reported to inhibit the DNA polymerase (15). A similar result was observed with betaine (Figure 3, Lanes 7-10), which was evaluated at concentrations of 0.5-2 M (i.e., in the concentration range recommended for this additive) $(15,23)$. Only with a betaine concentration of $2 \mathrm{M}$ was it possible to significantly reduce the second band at $650 \mathrm{bp}$, but in no case was it possible to obtain only the specific 522-bp fragment. Similar results were obtained with ethylene glycol, tested at concentrations of $0.5-1.5 \mathrm{M}$ (Figure 3, Lanes 11-13).

Analyzing $T_{m}$ values for the specific $A R X$ amplicon, we found the lowest $\mathrm{T}_{\mathrm{m}}$ value, $76.4^{\circ} \mathrm{C}$, occurred with the use of the analog, whereas the values for $10 \%$ DMSO, $2 \mathrm{M}$ betaine, and $1.5 \mathrm{M}$

\section{Make a Great Library.}

DNA size selection is a key aspect of many NGS workflows. The PippinHT not only automates this step, but improves the quality of results. For short-read sequencing or long-range genomics, make your library great.

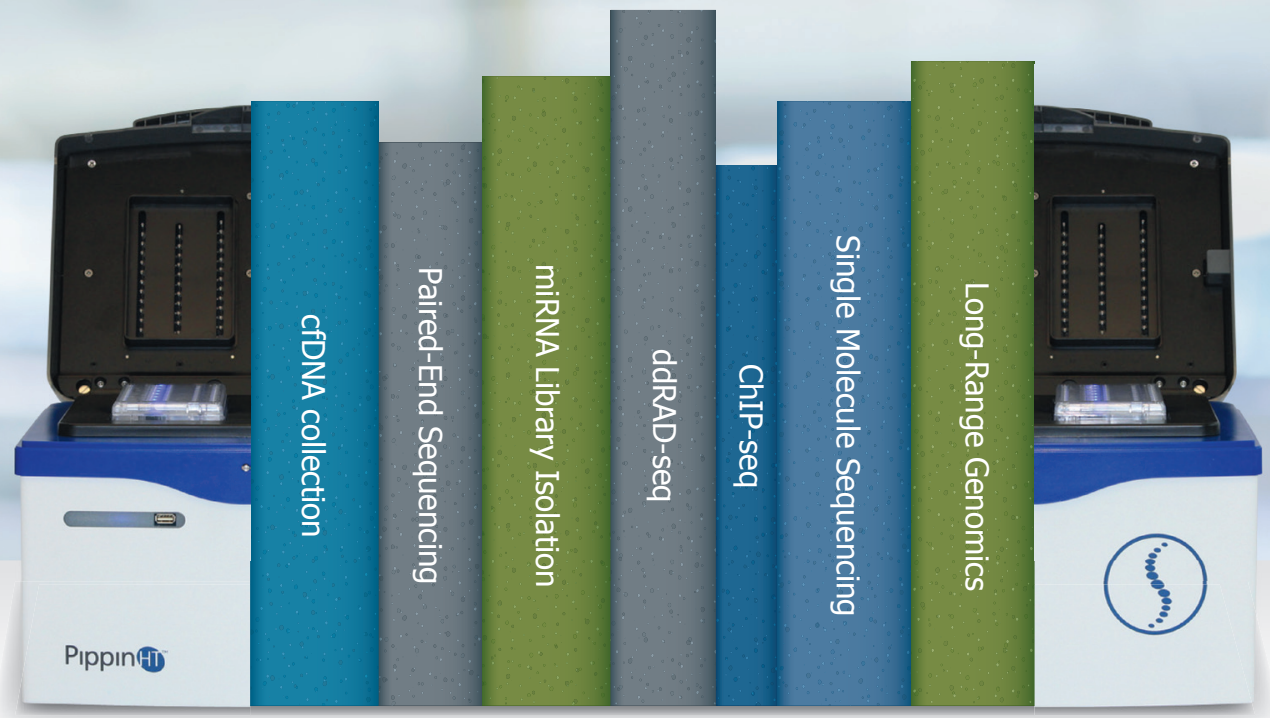

\section{PippinHT DNA Size Selection System}

- Precise and Reproducible

- Up to 24 Samples per Run
(1) sage science www.sagescience.com @SageSci 
ethylene glycol were $82.7^{\circ} \mathrm{C}, 81.5^{\circ} \mathrm{C}$, and $83.9^{\circ} \mathrm{C}$, respectively. This shows a greater ability of the $\mathrm{N}^{4} \mathrm{meC}$ nucleotide to reduce the stability of the DNA duplex, compared with the additives used at the highest concentrations recommended. Thus, $\mathrm{N}^{4} \mathrm{me}$-dCTP is more effective than the various additives tested, both in a functional sense, allowing PCR amplification of difficult DNA sequences, and in a physical sense, giving a larger reduction in the $T_{m}$ values.

The amplicons containing $\mathrm{N}^{4} \mathrm{meC}$ can be used for sequencing or for hybridization experiments (20). As to their use in cloning, this will depend on the particular restriction enzymes used in the cloning scheme, as the majority of restriction enzymes are inhibited by $\mathrm{N}^{4}$-methylation of cytosines in their recognition sequence $(24,25)$. In any event, performing PCR with $\mathrm{N}^{4}$ me-dCTP will be beneficial for hybridizations involving highly GC-rich regions. Regarding the amplification fidelity of $\mathrm{N}^{4}$ meC-containing DNA, sequencing data showed the expected sequence over hundreds of nucleotides. It should be noted that this does not address potential analog-mediated mutations occurring at lower but significant rates (1:100 or 1:1000 bp), which would have to be examined using cloning experiments. However, the fact that $\mathrm{N}^{4} \mathrm{meC}$ occurs routinely in the DNA of certain microorganisms (26-30) argues for relatively low mutation rates associated with incorporation of this nucleotide analog, at least for the polymerases used by these organisms.

\section{Author contributions}

C.R.F.J. performed the experiments. C.R.F.J. and R.C.P. designed the experiments and wrote the initial manuscript. E.G.J. and A.A. analyzed the data and contributed to the discussion and the final text. All authors read and approved the final manuscript.

\section{Acknowledgments}

This work was supported by the Secretaría de Investigación y Posgrado of the Instituto Politécnico Nacional (Grant SIP 20131256) and the Consejo Nacional de Ciencia y Tecnología-
CONACYT (Grant Ciencia Básica 61322). C.R.F.J. was the recipient of a graduate-student stipend from CONACYT.

\section{Competing interests}

The authors declare no competing interests.

\section{References}

1. Jung, A., S. Ruckert, P. Frank, T. Brabletz, and T. Kirchner. 2002. 7-Deaz"a-2'deoxyguanosine allows PCR and sequencing reactions from $\mathrm{CpG}$ islands. Mol. Pathol. 55:55-57.

2. Mamedov, T.G., E. Pienaar, J.R. TerMaat, G. Carvill, R. Goliath, A. Subramanian, and H. Viljoen. 2008. A fundamental study of the PCR amplification of GC-rich DNA templates. Comput. Biol. Chem. 32:452-457.

3. Dierick, H., M. Stul, W. Kelver, P. Marynen, and J.J. Cassiman. 1993. Incorporation of dITP or 7-deaza dGTP during PCR improves sequencing of the product. Nucleic Acids Res. 21:4427-4428.
4. Henke, W., K. Herdel, K. Jung, D. Schnorr, and S.A. Loening. 1997. Betaine improves the PCR amplification of GC rich DNA sequences. Nucleic Acids Res. 25:39573958.

5. Hubé, F., P. Reverdiau, S. lochmann, and Y. Gruel. 2005. Improved PCR Method for Amplification of GC-Rich DNA Sequences. Mol. Biotechnol. 31:81-84.

6. Musso, M., R. Bocciardi, S. Parodi, R. Ravazzolo, and I. Ceccherini. 2006. Betaine, Dimethyl Sulfoxide, and 7-DeazadGTP, a Powerful Mixture for Amplification of GC-rich DNA Sequences. J. Mol. Diagn. 8:544-550.

7. Wei, M., J. Deng, K. Feng, B. Yu, and Y. Chen. 2010. Universal Method Facilitating the Amplification of Extremely GC-Rich DNA Fragments from Genomic DNA. Anal. Chem. 82:6303-6307.

8. Orpana, A.K., T.H. Ho, and J. Stenman. 2012. Multiple heat pulses during PCR extension enabling amplification of GC-rich sequences and reducing amplification bias. Anal. Chem. 84:2081-2087.

9. Frey, U.H., H. Bachmann, J. Peters, and W. Siffert. 2008. PCR amplification of GC

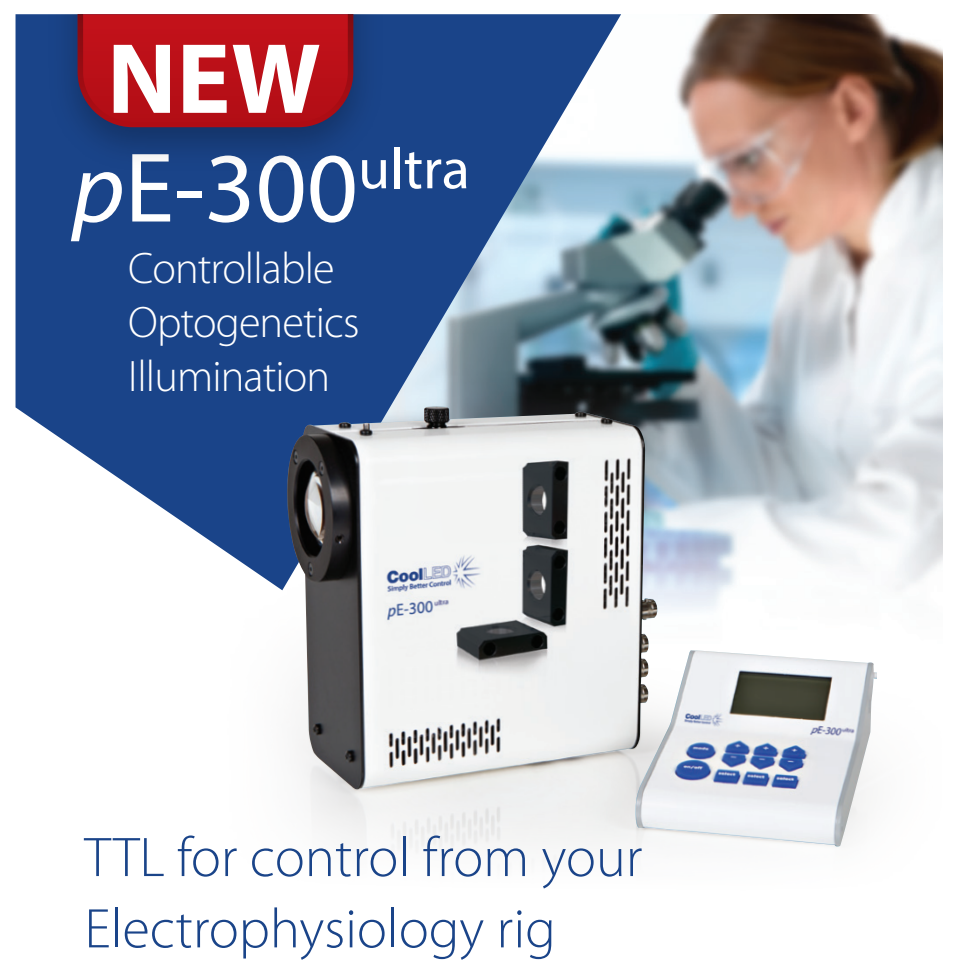

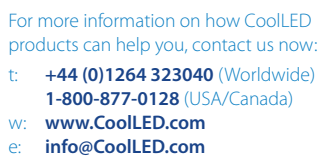

For more information on how CoolLED +44 (0)1264323040 (Worldwide) 1-800-877-0128 (USA/Canada) info@CoolLED.com

Launching at Neuroscience in November, Booth \#3227

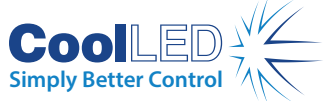

Simply Better Control 71

f尸e圆 in www.CoolLED.com 
